\title{
RANCANG BANGUN APLIKASI MONITORING HASIL PELATIHAN TENAGA KERJA DI DINAS TENAGA KERJA DAN TRANSMIGRASI (DISNAKERTRANS) KABUPATEN SUMBAWA BERBASIS ANDROID
}

\author{
Yana Karisma ${ }^{1}$, Shinta Esabella ${ }^{2}$, Henni Kuspitari ${ }^{3}$
}

$1^{*}$ Fakultas Teknik Universitas Teknologi Sumbawa

${ }^{2}$ Fakultas Teknik Universitas Teknologi Sumbawa

${ }^{3}$ Fakultas Teknik Universitas Teknologi Sumbawa

*Corresponding Author email: ${ }^{*}$ yana.karisma@uts.ac.id, ${ }^{2}$ shinta.esabella@uts.ac.id

\begin{tabular}{|c|c|}
\hline & Abstrak \\
\hline & Penelitian ini dilakukan dengan tujuan untuk merancang dan membangun \\
\hline & Aplikasi Monitoring Hasil Pelatihan Tenaga Kerja Di Dinas Tenaga Kerja dan \\
\hline & $\begin{array}{l}\text { Transmigrasi Kabupaten Sumbawa (DISNAKERTRANS) Berbasis Android. } \\
\text { Program di atas dimaksudkan agar pihak DISNAKERTRANS dapat mengetahui }\end{array}$ \\
\hline \multirow{2}{*}{$\begin{array}{l}\text { Diterima } \\
\text { Bulan Januari } \\
2020 \\
\text { Diterbitkan } \\
\text { Bulan Februari } \\
2020\end{array}$} & dan mengevaluasi kualitas pelatihan yang telah dilakukan serta mengetahui mutu \\
\hline & \\
\hline & \\
\hline & Sql. Adapun \\
\hline Aplik & metode pengujian aplikasi dari penelitian adalah black box. Aplikasi ini \\
\hline Monitoring , & bermanfaat bagi pihak DISNAKERTRANS kabupaten sumbawa untuk \\
\hline $\begin{array}{l}\text { Tenga kerja, } \\
\text { Instansi }\end{array}$ & a dan mengetahui tingkat keberhasilan \\
\hline
\end{tabular}

\section{PENDAHULUAN}

Perkembangan teknologi informasi yang begitu pesat merupakan jawaban dari kebutuhan umat manusia yang semakin hari selalu membutuhkan alternatif dalam hal pengolahan data. Dalam bidang pemerintahan penerapan teknologi informasi mampu membantu pemerintah seperti Dinas Tenaga Kerja Dan Transmigrasi (DISNAKERTRANS) untuk meningkatkan kualitas pelayanan kepada masyarakat baik dalam hal administrasi, monitoring hasil pelatihan maupun pelayanan informasi.

Dinas Tenaga Kerja Dan Transmigrasi (DISNAKERTRANS) Kabupaten Sumbawa merupakan dinas pemerintahan yang bergerak di bidang pelatihan tenaga kerja dan transmigrasi. Dalam satu tahun jumlah pendaftar peserta pelatihan tenaga kerja di DISNAKERTRANS bisa mencapai 300 orang. Akan tetapi yang menjadi permasalahan dalam pelatihan tenaga kerja ini adalah tidak adanya tindak lanjut atau monitoring oleh pihak DISNAKERTRANS terhadap para peserta pelatihan yang telah lulus untuk mengetahui apakah setelah mengikuti pelatihan tersebut mereka bisa mendapatkan pekerjaan dalam rentan waktu yang relatif singkat sesuai dengan keahlian yang mereka pelajari atau tidak. Akibatnya pihak DISNAKERTRANS tidak dapat mengetahui sejauh mana tingkat keberhasilan program pelatihan tenaga kerja yang dilaksanakan setiap tahunnya. Selain itu pihak DISNAKERTRANS juga tidak memiliki acuan untuk melakukan evaluasi terhadap pelaksanaan program pelatihan tenaga kerja yang dilaksanakan apakah efektif atau tidak. Padahal di masa ini perkembangan teknologi menawarkan penyelesaian terhadap masalah ini. Maka dari itu penulis memberikan sebuah solusi dengan merancang dan membangun aplikasi monitoring hasil pelatihan tenaga kerja di DISNAKERTRANS Kabupaten Sumbawa berbasis android.

Dengan adanya aplikasi ini, pihak DISNAKERTRANS dapat memonitoring para peserta pelatihan yang telah lulus, apakah sesudah mengikuti pelatihan tersebut mereka bisa mendapatkan pekerjaan sesuai dengan bidang keahlian yang mereka ikuti atau tidak. Data hasil dari proses monitoring ini akan menjadi ukuran sejauh mana efektifitas atau tingkat keberhasilan program pelatihan tenaga kerja yang dilaksanakan oleh pihak DISNAKERTRANS tiap tahunnya. Selain itu data hasil proses monitoring ini akan menjadi bahan evaluasi pihak DISNAKERTRANS untuk bagaimana meningkatkan kualitas pelatihan yang dilaksanakan guna meningkatkan efektifitas atau tingkat keberhasilan program pelatihan tersebut. 


\section{LANDASAN TEORI}

\section{Rancang Bangun Aplikasi}

Penulis memaparkan definisi rancang bangun menurut Sembiring (2013: 46) dan Lestariningsih, Ardianto dan Handoko (2015: 103). Aplikasi dapat diartikan juga sebagai program komputer yang dibuat untuk menolong manusia dalam melaksanakan tugas tertentu (Sembiring, 2013: 46).

Rancang bangun merupakan aktifitas menerjemahkan hasil analisis terhadap suatu objek ke dalam bentuk software kemudian menghasilkan sebuah sistem baru ataupun mengembangkan sistem yang sudah ada (Lestariningsih, Ardianto dan Handoko, 2015: 103).

Berkaca dari kedua definisi di atas mengenai rancang bangun dan aplikasi, maka dapat disimpulkan bahwa rancang bangun aplikasi yaitu kegiatan menterjemahkan hasil inalisis suatu sistem ke dalam bentuk perangkat lunak untuk memudahkan dan meningkatkan kualitas suatu kegiatan atau pekerjaan.

\section{Monitoring}

Monitoring adalah kegiatan mengamati suatu objek dengan tujuan untuk mengetahui perkembangan, mengidentifikasi permasalahan serta menemukan upaya pemecahannya (Yumari dan Mulyono, 2017: 9).

\section{Pelatihan}

Pelatihan adalah suatu kegiatan yang dilaksanakan dengan tujuan meningkatkan pengetahuan, keterampilan, kinerja dan perilaku seseorang ataupun kelompok (Santoso, 2010: 2).

\section{Android}

Android merupakan platform generasi baru untuk perangkat mobile yang memungkinkan pengembang untuk melakukan pengembangan sesuai dengan yang diinginkan. Sistem operasi android bernaung di bawah GNU. General public License Version 2 (GPLv2) yang biasa dikenal dengan istilah copyleft (Fatoni dan Rendra, 2014: 23-24).

\section{MATODE PENELITIAN}

Penelitian ini dilakukan dengan jenis penelitian kualitatif yang bersifat deskriptif. Penelitian kualitatif merupakan jenis penelitian yang tidak diperoleh melalui prosedur perhitungan atau statistik (Sugiarto, 2015: 8). Kemudian dalam penelitian ini metode pengembangan perangkat lunak yang digunakan adalah metode waterfall. Metode waterfall adalah model klasik yang sistematis dalam membangun sebuah perangkat lunak (Pressman, 2012: 46).

Dalam penelitian kualitatif ada tiga proses utama yang harus dilakukan yaitu pengumpulan data, analisis data dan keabsahan temuan. Pelaksanaan penelitian ini diawali dengan tahapan pengumpulan data pelatihan tenaga kerja yang dilaksanakan oleh pihak DISNAKERTRANS kabupaten Sumbawa. Setelah data yang dibutuhkan didapatkan tahapan berikutnya adalah proses pengembangan perangkat lunak yang meliputi kegiatan komunikasi, perencanaan, pemodelan aplikasi, konstruksi dan implementasi. Berikut adalah penjelasan mengenai metode dan tahapan pengembangan perangkat lunak yang digunakan dalam penelitian ini:

\section{Kualitatif}

Berikut adalah tahapan-tahapan kualitatif dalam penelitian ini.

\section{Pengumpulan Data.}

Adapun metode pengumpulan data yang digunakan dalam penelitian ini adalah :

\section{Wawancara.}

Wawancara adalah proses yang dilakukan dengan cara mewawancarai pihak-pihak yang mampu untuk memberikan informasi kepada penulis. Dalam hal ini penulis mewawancarai pimpinan DISNAKERTRANS untuk mendapatkan data mengenai permasalahan yang dialami menyangkut kegiatan pelatihan yang diadakan.

\section{Studi Pustaka.}

Studi pustaka merupakan metode pengumpulan data yang diarahkan kepada pencarian data dan informasi melalui dokumen-dokumen, baik dokumen tertulis, foto-foto, gambar, maupun dokumen elektronik yang dapat mendukung dalam proses penulisan. Dalam hal ini penulis mendapatkan refrensi dari data peserta pelatihan, data instruktur pelatihan, data paket pelatihan dan data job fair.

\section{Analisis Data.}

Analisa data dilakukan untuk mengetahui jenis atau kategori data agar memudahkan proses pengelompokkan dan pengolahan pada aplikasi Monitoring Hasil Pelatihan Tenaga Kerja di Dinas Tenaga Kerja dan Transmigrasi (DISNAKERTRANS) kabupaten Sumbawa berbasis Android. 


\section{Keabsahan Temuan.}

Kegunaan keabsahan temuan yaitu untuk memastikan data yang dimiliki valid atau tidak, sehingga tahapan penelitian dapat dilanjutkan ke tahap perancangan. Temuan keabsahan dalam penelitian ini dilakukan dengan cara memvalidasi hasil analisa data kepada narasumber yaitu pimpinan DISNAKERTRANS.

\section{Metode Pengembangan Perangkat Lunak.}

Pada proses analisis dan perancangan aplikasi penulis mengunakan metode pengembangan perangkat lunak waterfall. Model waterfall adalah model klasik yang bersifat sistematis, berurutan dalam membangun software.

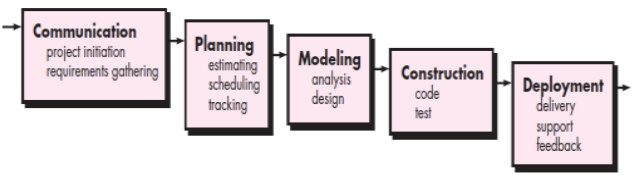

Gambar 3.1 Metode Waterfall

Berikut adalah fase-fase dalam model waterfall:

\section{Communication (Komunikasi).}

Dalam pembuatan aplikasi Monitoring Hasil Pelatihan Tenaga Kerja berbasis Android tahapan pertama yang dilakukan oleh developer adalah mendiskusikan spesifikasi dan kebutuhan dari aplikasi yang akan dibangun dengan client.

\section{Planning (Perencanaan).}

Dalam tahapan perencanaan ini terdapat dua proses, yaitu yang pertama adalah perhitungan estimasi waktu dan biaya yang dibutuhkan untuk membangun aplikasi Monitoring Hasil Pelatihan Tenaga Kerja Berbasis Android ini. Kemudian proses yang kedua adalah penjadwalan pengerjaan tahapan dan proses-proses berikutnya.

\section{Modeling (Pemodelan).}

Dalam tahapan ini terdapat dua proses, yaitu yang pertama adalah analisis yang meliputi analisis terhadap kebutuhan software, analisis kebutuhan hardware, dan analisis kebutuhan data yang dibutuhkan dalam pembuatan aplikasi Monitoring Hasil Pelatihan Tenaga Kerja Berbasis Android. Kemudian proses yang kedua adalah perancangan yang meliputi perancangan sistem,perancangan database dan perancangan tampilan aplikasi.

\section{Construction (Konstruksi).}

Dalam tahapan ini terdapat dua proses, yaitu pengkodean dan uji coba terhadap aplikasi yang dibangun. Uji coba dimaksudkan untuk mengetahui apakah aplikasi Monitoring Hasil Pelatihan Tenaga Kerja berbasis Android yang telah dibangun benarbenar sesuai dengan apa yang telah direncanakan.

\section{Deployment (Implementasi).}

Tahapan ini merupakan final dalam pembuatan aplikasi Monitoring Hasil Pelatihan Tenaga Kerja berbasis Android. Aplikasi yang telah dibuat harus dilakukan pemeliharaan secara berkala. Dan pada tahapan ini aplikasi siap diimplementasikan.

\section{Alur Penelitian}

Berikut adalah alur penelitian yang dilakukan dalam pembuatan Aplikasi Monitoring Hasil Pelatihan Tenaga Kerja Dan Transmigrasi (DISNAKERTRANS) kabpaten Sumbawa.

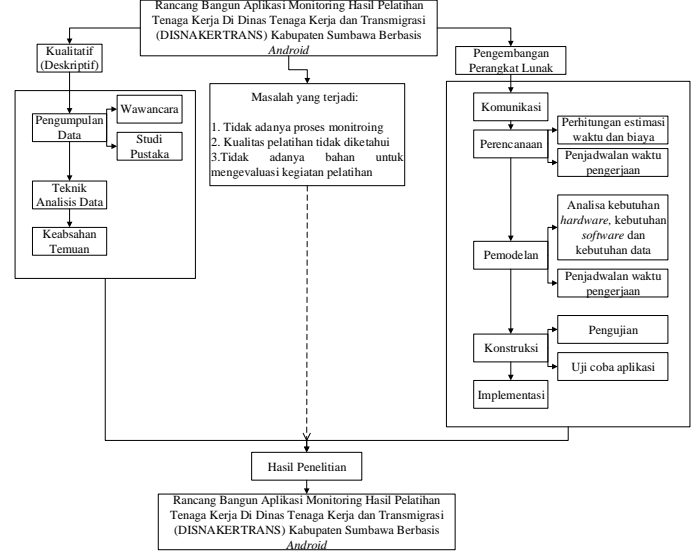

Gambar 3.2 Alur Penelitian

\section{HASIL DAN PEMBAHASAN}

\section{Flowchart}

Flowchart merupakan sebuah diagram yang mempresentasikan arus atau alur kerja dari suatu sistem (Saputra, 2012: 121). Berikut adalah flowchart dari aplikasi monitoring hasil pelatihan tenaga kerja berbasis android.

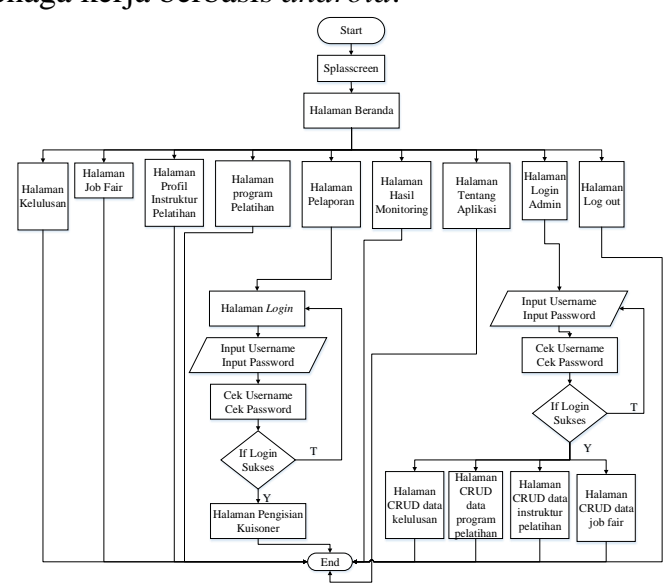

Gambar 4.1. Flowchart Aplikas 


\section{Diagram Konteks}

Berikut adalah diagram konteks dari aplikasi monitoring hasil pelatihan tenaga kerja di DISNAKERTRANS kabupaten sumbawa berbasis android.

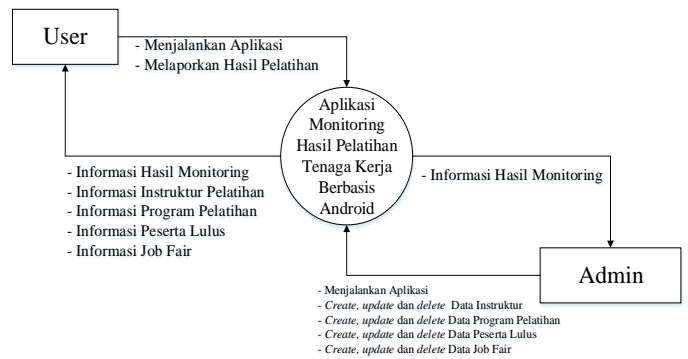

Gambar 4.2. Diagram Konteks

\section{Entity Relationship Diagram (ERD)}

ERD yaitu model E-R yang di dalamnya terdapat himpunan komponen entitas dan himpunan relasi. Himpunan ini masing-masing disertai dengan atribut-atribut yang merupakan representasi dari seluruh fakta pada dunia nyata (Fatansyah, 2012: 81-82). Berikut adalah ERD dari Aplikasi Monitoring Hasil Pelatihan Tenaga Kerja di DISNAKERTRANS kabupaten sumbawa berbasis Android.

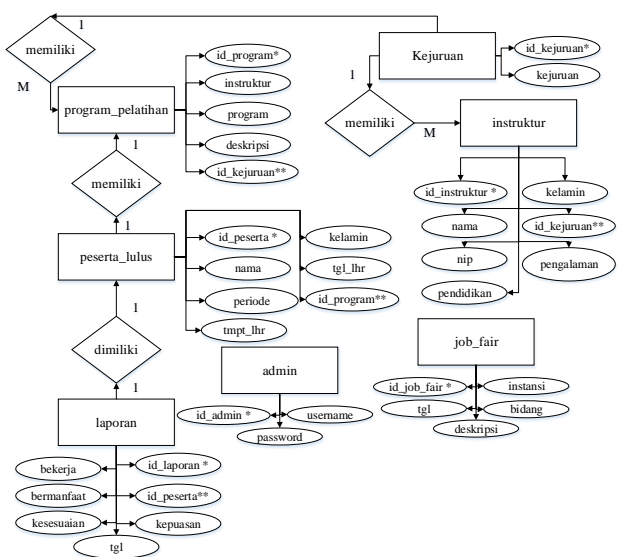

Gambar 4.3. Entity Relationship Diagram (ERD)

\section{Rancangan Database Aplikasi}

Perancangan database dari aplikasi monitoring hasil pelatihan tenaga kerja di dinas tenaga kerja dan transmigrasi (DISNAKERTRANS) kabupaten sumbawa berbasis android menggunakan database MySQL. Mysql yaitu sebuah program aplikasi yang digunakan untuk membangun sebuah database yang umumnya digunakan pada layanan web (wibawa, 2017: 78). Berikut adalah struktur tabel dari aplikasi: a. Tabel Peserta Lulus.

Berikut adalah struktur tabel peserta lulus dari Aplikasi Monitoring Hasil Pelatihan Tenaga Kerja Di Dinas Tenaga berbasis Android:

Tabel 4.1. Struktur Tabel Peserta Lulus

\begin{tabular}{|l|l|l|l|}
\hline \multicolumn{1}{|c|}{ Field } & \multicolumn{1}{|c|}{ Type } & \multicolumn{1}{c|}{$\begin{array}{c}\text { Ukuran } \\
\text { Field }\end{array}$} & Keterangan \\
\hline id_peserta & Int & 4 & Primary Key \\
\hline id_program & Int & 2 & Foreign Key \\
\hline Nama & Varchar & 100 & \\
\hline Kelamin & Enum & $\begin{array}{l}\text { Laki-laki, } \\
\text { Perempuan }\end{array}$ & \\
\hline tmpt_lhr & Varchar & 100 & \\
\hline tgl_lhr & Date & & \\
\hline Periode & Varchar & 6 & \\
\hline
\end{tabular}

b. Tabel Kejuruan.

Berikut adalah struktur tabel kejuruan dari Aplikasi Monitoring Hasil Pelatihan Tenaga Kerja Di Dinas Tenaga berbasis Android:

Tabel 4.2 Struktur Tabel Kejuruan

\begin{tabular}{|l|l|l|l|}
\hline \multicolumn{1}{|c|}{ Field } & \multicolumn{1}{|c|}{ Type } & $\begin{array}{c}\text { Ukuran } \\
\text { Field }\end{array}$ & Keterangan \\
\hline id_kejuruan & Int & 2 & Primary Key \\
\hline Kejuruan & Varchar & 100 & \\
\hline
\end{tabular}

c. Tabel Program_Pelatihan.

Berikut adalah struktur tabel program_pelatihan dari Aplikasi Monitoring Hasil Pelatihan Tenaga Kerja Di Dinas Tenaga berbasis Android.

Tabel 4.3 Struktur Tabel Program_Pelatihan

\begin{tabular}{|l|l|l|l|}
\hline \multicolumn{1}{|c|}{ Field } & Type & $\begin{array}{c}\text { Ukuran } \\
\text { Field }\end{array}$ & Keterangan \\
\hline id_program & Int & 2 & $\begin{array}{l}\text { Primary } \\
\text { Key }\end{array}$ \\
\hline id_kejuruan & Int & 2 & $\begin{array}{l}\text { Foreign } \\
\text { Key }\end{array}$ \\
\hline Program & Varchar & 100 & \\
\hline
\end{tabular}




\begin{tabular}{|l|l|l|l|}
\hline Instruktur & Varchar & 50 & \\
\hline Deskripsi & Text & & \\
& & & \\
\hline
\end{tabular}

\section{Relasi Antar Tabel}

Relasi antar tabel digunakan untuk menunjukkan hubungan secara logika diantara table-tabel yang terbentuk. Dalam aplikasi Monitoring Hasil Pelatihan Tenaga terdapat tujuh tabel. Untuk lebih jelasnya mengenai rancangan database dan tabel penyusunan aplikasi Monitoring Hasil Pelatihan Tenaga Berbasis Android, berikut adalah relasi antartabelnya.

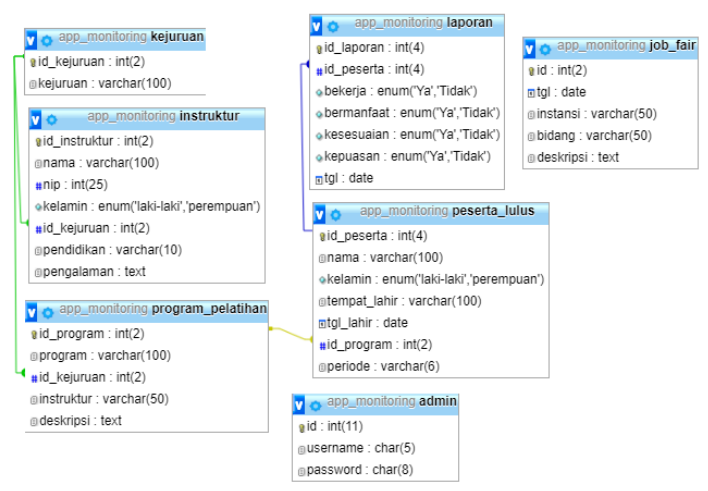

Gambar 4.4. Relasi Antar Tabel

\section{Rancangan User Interface}

Berikut adalah rancangan user interface aplikasi Monitoring Hasil Pelatihan Tenaga Kerja Berbasis Android.

a. Rancangan Halaman Beranda.

Berikut adalah rancangan tampilan halaman beranda dari aplikasi Monitoring Hasil Pelatihan Tenaga Kerja berbasis Android:

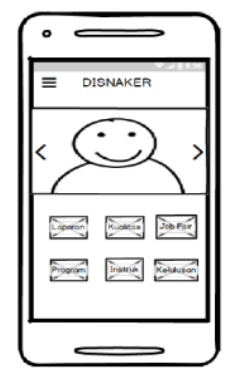

Gambar 4.5. Rancangan Halaman Beranda

b. Rancangan Halaman Pelaporan

Berikut adalah rancangan tampilan halaman pelaporan dari aplikasi Monitoring Hasil Pelatihan Tenaga Kerja berbasis Android

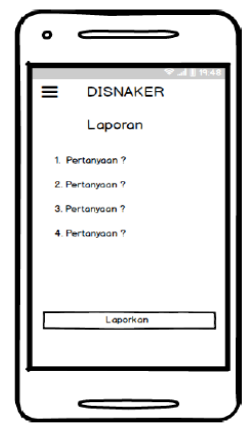

Gambar 4.6. Rancangan Halaman Pelaporan

c. Rancangan Halaman Hasil Monitoring.

Berikut adalah rancangan tampilan halaman hasil monitoring dari aplikasi Monitoring Hasil Pelatihan Tenaga Kerja berbasis Android:

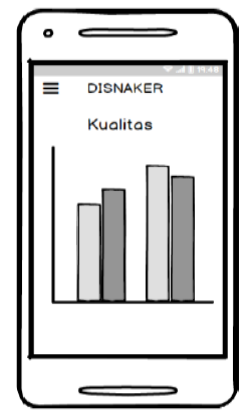

Gambar 4.7. Rancangan Halaman Hasil Monitoring

\section{Implementasi Program}

Berikut adalah implementasi program dari Aplikasi Monitoring Hasil Pelatihan Tenaga Kerja berbasis Android:

a. Tampilan Beranda.

Berikut ini adalah tampilan halaman beranda dari Aplikasi Monitoring Hasil Pelatihan Tenaga Kerja berbasis Android.

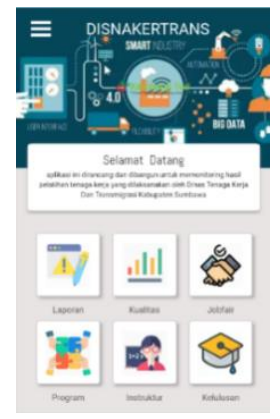

Gambar 4.8. Tampilan Halaman Beranda

b. Tampilan Halaman Pelaporan.

Berikut ini adalah tampilan halaman pelaporan dari Aplikasi Monitoring Hasil Pelatihan Tenaga Kerja berbasis Android. 


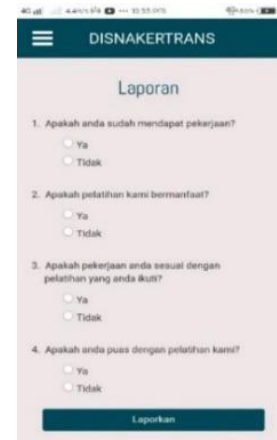

Gambar 4.9. Tampilan Halaman Pelaporan

c. Tampilan Halaman Hasil Monitoring.

Berikut ini adalah tampilan halaman hasil monitoring atau kualitas pelatihan dari Aplikasi Monitoring Hasil Pelatihan Tenaga Kerja berbasis Android.

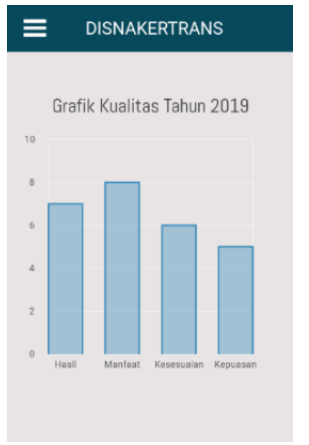

Gambar 4.10. Tampilan Halaman Kualitas Pelatihan

\section{PENUTUP}

\section{Kesimpulan}

Kesimpulan yang dapat ditarik dari penelitian ini adalah Aplikasi Monitoring Hasil Pelatihan Tenaga Kerja Berbasis Android berhasil dibangun mengunakan HTML 5, CSS 3 dan PHP 5.6 basis data MySQL, minimum android versi 4.4 kitkat serta telah diuji menggunakan metode pengujian blackbox. Informasi yang disajikan dalam aplikasi ini yaitu pelaporan hasil pelatihan, kualitas dari pelatihan, instruktur pelatihan, program pelatihan, job fair, kelulusan atau peserta yang telah lulus pelatihan dan tentang aplikasi. Dengan terselesaikannya aplikasi ini penulis berharap dapat dijadikan sebagai masukkan bagi pihak DISNAKERTRANS untuk memudahkan dalam hal melakukan proses monitoring hasil pelatihan tenaga kerja. Dengan demikian, penelitian ini dapat memberikan kemudahan pada pihak DISNAKERTRANS dalam mengetahui kualitas dari pelatihan yang diadakan.

\section{REFERENSI}

Fatansyah. (2012). Basis Data. Bandung: Informatika.

Fatoni, Ahmad., \& Rendra, Dwi Bayu. (2014). "Perancangan Prototype Sistem Kendali Lampu Menggunakan Handphone Android Berbasis Arduino". Jurnal PROSISKO. Vol.1. Hlm.23-24.

Lestariningsih, Endang., Ardianto, Eka \& Handoko, W. (2015). "Rancang Bangun E-Office Administrasi Surat di Baigian Humas Universitas Stikubank Semarang”.Jurnal Dinamika Informatika. Vol. 7 No. 2 hal. 103. Tanggal Akses: 6 Maret 2019.

Pressman, Roger S. (2012). Rekayasa Perangkat Lunak. Buku 1. Pendekatan Praktisi Edisi 7. Diterjemahkan Oleh Adi Nugroho.Yogyakarta: Andi.

Santoso, Budi. (2010). Skema dan Mekanisme Pelatihan. Jakarta: Terangi.

Saputra, Agus. (2012). Membangun Aplikasi Toko Online Dengan PHP dan SQL Server. Jakarta: PT Elex Media Koputindo.

Sembiring, Sandro. (2013). "Perancangan Aplikasi Steganografi Untuk menyisipkan Pesan Text Pada Gambar Dengan Metode End of File". Jurnal Pelita Informatika Budi Darma. Vol. 4 No.2 Hal. 46. Tanggal Akses: 6 Maret 2019.

Sugiarto, Eko. (2015). Menyusun Proposal Penelitian Kualitatif: Skirpsi dan Tesis. Yogyakarta: Suaka Media.

Wibawa, Julian Chandra. (2017). "Rancang Bangun Sistem Informasi Akademik (Studi Kasus: SMPIT Nurul Islam Tengaran)". Jurnal Infotronik. Vol 2 No. 2 Hal.78.

Yumari., \& Mulyono. (2017). Strategi Monitoring dan Evaluasi Pelaksanaan Anggaran. Yogyakarta: Deepublish. 